\title{
GAMBARAN PENGETAHUAN REMAJA TENTANG KESEHATAN REPRODUKSI DI SMP NEGERI 3 SELEMADEG TIMUR TAHUN 2019
}

\author{
Cokorda Istri Mita Pemayun ${ }^{1,2}$, Made Dewi Saryani ${ }^{1,2}$, Lakitha Ning Utami ${ }^{1,2}$ \\ ${ }^{1}$ Program Studi DIII Kebidanan, ${ }^{2}$ STIKes Advaita Medika Tabanan \\ Korespodensi penulis: mid.cokp@gmail.com
}

\begin{abstract}
Abstrak
Latar belakang dan tujuan: Masa remaja adalah masa peralihan dari anak-anak kedewasa yang ditandai perubahan fisik, emosi dan psikis. Pengetahuan tentang kesehatan reproduksi sangat penting bagi remaja untuk meningkatkan perilaku kesehatan, menghindari sex bebas, dan penurunan jumlan infeksi menular seksual. Tujuan penelitian ini untuk menggambarkan pengetahuan remaja tentang kesehatan reproduksi.

Matode: Desain penelitian ini merupakan deskriptif kuantitatif. Penelitian ini dilaksanakan pada bulan 23 Mei 2019 di SMP Negeri 3 Selemadeg Timur. Sampel dipilih menggunakan purposve sampling. Sample yang digunakan adalah 50 orang. Instrument yang digunakan untuk mengukur pengetahuan menggunakan kuesioner. Analisa data menggunakan uji chi-square.

Hasil: Hasil penelitian dari 50 orang siswa/i yang didistribusikan kedalam sub pokok bahasan tentang kesehatan reproduksi menunjukkan bahwa 29 orang $(58 \%)$ mengetahui pengertian kesehatan reproduksi; 26 orang (52\%) mengetahui hak kesehatan reproduksi; 42 orang (84\%) tidak mengetahui pertumbuhan dan perkembangan masa remaja; 35 orang $(70 \%)$ tidak mengetahui fungsi reproduksi; 26 orang (52\%) mengetahui tanda kematangan organ reproduksi dan sebanyak 42 orang (84\%) tidak mengetahui penyakit menular seksual.

Simpulan: Data menunjukan bahwa remaja yang memiliki pengetahuan baik masih sedikit sehingga untuk penelitian selanjutnya diharapkan untuk memberikan intervensi agar pengetahuan responden dapat meningkat.
\end{abstract}

Kata Kunci: Kesehatan Reproduksi, Pengetahuan, Remaja,

\section{Pendahuluan}

Kesehatan reproduksi adalah termasuk salah satu dari sekian banyak problem remaja yang perlu mendapat perhatian bagi semua kalangan, baik orang tua, guru, dan maupun konselor sekolah. Kurangnya pengetahuan kesehatan reproduksi dan kehidupan rumah tangga serta adat istiadat yang merasa malu kawin tua (perawan tua) menyebabkan meningkatnya seks pranikah, perkawinan usia remaja, dan kehamilan usia remaja, sehingga dapat menyebabkan penyakit kanker leher rahim (Sugiharta, 2004).

Hasil analisis Direktorat Jendral Kesehatan Masyarakat Depkes dan Kesejahteraan Masyarakat dan Kesejahteraan Sosial RI (2010), menunjukkan bahwa kondisi kesehatan reproduksi di Indonesia dewasa ini belum seperti yang diharapkan, bila dibandingkan dengan keadaan di Negaranegara ASEAN lainnya. Indonesia masih tertinggal jauh dalam aspek kesehatan reproduksi termasuk kesehatan reproduksi remaja (BKKBN, 2012).

Permasalahan utama yang dialami oleh remaja Indonesia yaitu ketidaktahuan terhadap tindakan yang harus dilakukan sehubungan dengan perkembangan yang sedang dialami, khususnya masalah kesehatan reproduksi remaja. Hal tersebut ditunjukkan dengan masih rendahnya pengetahuan remaja tentang kesehatan reproduksi remaja. Remaja perempuan yang mengetahui tentang masa subur sebanyak $29 \%$ dan remaja laki-laki sebanyak 32,2\%, remaja perempuan dan remaja laki-laki yang 
mengetahui resiko kehamilan jika melakukan hubungan seksual untuk pertama kali masingmasing baru mencapai $49,5 \%$ dan $45,5 \%$. Remaja perempuan dan laki-laki usia 14-19 tahun mengaku pernah melakukan hubungan seksual sebelum menikah masing-masing mencapai 34,7\% dan 30,9\% (BKKBN, 2012).

Hasil dari Survey Kesehatan Reproduksi Remaja Indonesia tahun 2007 (SKKRI) menunjukkan bahwa $12 \%$ remaja putri dan $29 \%$ remaja laki-laki tidak membahas kesehatan reproduksi dengan seseorang. Mayoritas remaja membahas isu kesehatan reproduksi bersama teman sebaya $(71 \%$ wanita dan 58\% laki-laki) (SKRRI, 2007). Hasil penelitian yang dilakukan mahasiswa Fakultas Kesehatan Masyarakat, Universitas Diponegoro bahwa pengetahuan remaja tentang kesehatan reproduksi pada umumnya "sangat rendah" (lebih dari 75\% remaja) (Suryoputro, 2006).

Pemahaman remaja tentang kesehatan reproduksi masih ada yang sangat kurang sampai saat ini. Remaja ada yang masih beranggapan bahwa melakukan hubungan seksual sekali ataupun mandi setelah berhubungan seksual tidak menyebabkan kehamilan (Pangkahila, 2004). Para orang tua lebih cenderung menganggap ringan masalah kesehatan reproduksi. Mereka lebih mempercayai lembaga sekolah atau institusi yang terkait untuk menyampaikan pendidikan kesehatan reproduksi kepada anak-anaknya (Dianawati, 2003).

Hal tersebut dibuktikan dengan penelitian Soetjiningsih terhadap 398 siswa SMA di daerah perkotaan Yogyakarta menunjukkan bahwa dari $84 \%$ siswa yang tidak setuju dengan perilaku seks pra nikah, 95\% dari mereka menyatakan pernah mendapat pendidikan yang berkaitan dengan seksualitas, dan mereka $(94,80 \%)$ juga setuju dengan pemberian pendidikan seks bagi kalangan remaja dan figure yang dianggap cocok memberikan pendidikan seks adalah dokter, psikolog dan seksolog (PKBI, 2009).

Keterbatasan akses informasi bagi remaja Indonesia mengenai kesehatan reproduksi yang di dalamnya mencakup seksualitas disebabkan karena masyarakat beranggapan bahwa seksualitas masih dianggap tabu. Orang tua biasanya masih risih untuk membicarakan masalah kesehatan reproduksi dan seksualitas pada anaknya yang mulai tumbuh menjadi remaja, dan anak remaja cenderung merasa malu untuk bertanya dan bercerita tentang apa yang terjadi pada remaja tersebut kepada orangtuanya. Sehingga sedikit remaja yang memperoleh informasi mengenai kesehatan reproduksi terutama pendidikan seks dari orangtuanya (BKKBN, 2012).

Sesuai dengan hasil penelitian tentang faktor yang berpengaruh terhadap perkembangan kesehatan reproduksi pada remaja, yaitu $64 \%$ dari orang tua, dan $68,4 \%$ dari teman. Hal ini menjadi salah satu ciri khas remaja, dimana para remaja ini memiliki sikap tertutup pada orang dewasa atau orang tua dan terbuka terhadap kelompok teman sebaya (Utama, 2013).

Tidak tersedianya informasi yang akurat dan benar mengenai kesehatan reproduksi membuat remaja mencari akses dan mengeksplorasi sendiri. Remaja sering kali menggunakan media internet, televisi, majalah dan bentuk media massa lainnyayang dijadikan sebagai sumber informasi, untuk memenuhi rasa keingintahuan remaja tentang reproduksi atau seksualitas. Oleh karena itu remaja memerlukan informasi tentang kesehatan reproduksi dengan benar sehingga diharapkan remaja akan memiliki sikap dan tingkah laku yang bertanggung jawab menegenai organ dan proses reproduksinya sendiri.

Fakta mengenai kesehatan reproduksi di negara ini sangat beragam, di satu sisi sekolah yang berlingkup perkotaan dan berprestasi di Yogyakarta mendapat penyuluhan dan pembelajaran mengenai kesehatan reproduksi serta tidak setuju dengan perilaku seks pra nikah, sedangkan siswa yang berlingkup di daerah pedesaan di provinsi Jawa Tengah masih ada yang mempunyai tingkat pengetahuan kesehatan reproduksi yang kurang, menikah terlalu muda dan bahkan melakukan seks pranikah yang mempunyai banyak akibat untuk dirinya. 
Berawal dari keprihatinan para tokoh masyarakat antara lain dokter, ahli kandungan dan kebidanan terhadap keselamatan ibu dan anak, maka kebijakan pemerintah tanggal 23 Desember 1957, didirikan Perkumpulan Keluarga Berencana Indonesia (PKBI). Salah satu program PKBI sebagai Pusat Informasi dan Layanan Remaja (PKBI, 2009).

Dalam hal ini bidan sebagai petugas kesehatan dalam menjalankan perannya sebagai pendidik memberikan pendidikan dan penyuluhan tentang kesehatan reproduksi pada remaja. Bidan sebagai pelaksana dalam karirnya mempunyai tugas mandiri yaitu salah satunya memberikan pelayanan pada remaja tentang kesehatan reproduksi.

Masa remaja adalah masa dengan rentang usia berkisar 10 sampai 24 tahun. Masa ini merupakan suatu fase peralihan dari masa kanak-kanak (dependent) menuju masa dewasa (independent) dan normal terjadi pada kehidupan manusia. Dalam periode tersebut seorang remaja banyak mengalami perkembangan dan pertumbuhan guna mencari identitas dan jati dirinya. Berbagai perubahan akan muncul baik dari sisi psikologis, fisik (pubertas) dan sosial lingkungan.

Problematika kaum remaja dapat terjadi sehubungan dengan adanya perbedaan kebutuhan (motif) dan aktualisasi dari kemampuan penyesuaian diri (adaptasi) remaja terhadap lingkungan tempat hidupnya dan tumbuh berkembang sebagai seorang pribadi manusia dan makhluk sosial. Masa transisi ini merupakan masa yang kritis bagi remaja, disaat muncul keinginan lepas mandiri dari ketergantungan orang tua, rasa ingin tahu yang berlebihan dan mulai rentan terhadap perilaku beresiko.

Diperkirakan 20-30\% dari total populasi di masing-masing kabupaten maupun kotamadya di Indonesia adalah tergolong kaum remaja yang persentasenya terdistribusi secara hampir merata. Jika diestimasi dari jumlah penduduk Indonesia saat ini sekitar 250 juta, maka diperkirakan terdapat total 5075 juta jiwa kaum remaja. Khusus di Bali, terdapat sekitar 700.000-850.000 remaja dari keseluruhan sejumlah 3,5 juta jiwa penduduk di Bali. Apabila kita meninjau lebih jauh lagi, maka terdapat sekitar 1 milyar penduduk dunia adalah kaum remaja (hampir 1 dari 6 penduduk) dan $85 \%$ remaja ternyata hidup di negara berkembang. Melihat keadaan piramida penduduk yang terbalik, hendaknya remaja mendapatkan prioritas perhatian dari semua pihak yang bersangkutan.

Ditemukan fakta ternyata banyak remaja yang sudah aktif secara seksual, meskipun tidak selalu atas kehendak sendiri. Di beberapa negara berkembang kira-kira separuh dari mereka sudah menikah. Aktifitas seksual dini yang tidak bertanggungjawab menempatkan remaja menghadapi berbagai tantangan resiko kesehatan reproduksi. Di seluruh dunia. Pada tahun 1997 diperkirakan 15 juta jiwa lebih remaja putri berusia 15-19 tahun yang melahirkan, 4 juta diantaranya melakukan unsafe abortion dan hampir 100 juta orang remaja yang terkena IMS. Secara global pun didapatkan data $40 \%$ dari total kasus HIV terjadi pada kaum muda yang berusia 15-24 tahun atau diperkirakan lebih dari 7.000 remaja terinfeksi HIV setiap harinya.

Sedangkan di Indonesia sendiri, ditemukan prediksi sekitar 700.000 ribu kasus aborsi pada tahun 2003 dan 50\% termasuk unsafe abortion. KTD pada remaja Indonesia juga diestimasikan meningkat setiap tahunnya sebesar 150.000-200.000, 10\% remaja usia 15-19 tahun sudah menikah dan memiliki anak. Berbagai risiko kesehatan ini dipengaruhi oleh berbagai faktor yang saling berhubungan, misalnya tuntutan kawin muda dan berhubungan seksual, kurangnya akses terhadap pendidikan dan pekerjaan, ketimpangan gender, kekerasan seksual, pengaruh negatif media masa dan kemajuan teknologi, maupun gaya hidup modern yang bebas.

Penyuluhan kesehatan reproduksi ini akan dilaksanakan di SMP Negeri 3 Selemadeg Timur Tabanan. Jumlah siswa 239 orang dengan distribusi sebagai berikut: 83 orang kelas VII, 66 orang kelas VIII dan 90 orang kelas IX. Jumlah siswa perempuan sebanyak 120 orang dan laki-laki 119 orang. 
Berdasarkan hasil studi pendahuluan yang dilakukan pada 10 orang siswa SMP Negeri 3 Selemadeg Timur diperoleh hasil $30 \%$ memiliki pengetahuan baik tentang kesehatan reproduksi dan sisanya $70 \%$ memiliki pengetahuan yang kurang.

Melihat hasil studi pendahuluan tersebut dan mengingat pentingnya pendidikan kesehatan reproduksi bagi remaja, maka berdasarkan latar belakang di atas kami akan melaksanakan penyuluhan terkait kesehatan reproduksi remaja pada siswa SMP Negeri 3 Selemadeg Timur, dengan harapan pengetahuan siswa tentang kesehatan reproduksi meningkat. Dengan demikian diharapkan siswa mampu untuk menjadi remaja yang disiplin dan bertanggungjawab terhadap kesehatan reproduksinya sendiri.

Berdasarkan uraian latar belakang diatas peneliti tertarik untuk mengetahui lebih jauh tentang gambaran pengetahuan remaja, dengan rumusan masalah "Bagaimana Gambaran Pengetahuan Remaja Tentang Kesehatan Rfeproduksi di SMP Negeri 3 Selemadeg Timur"

\section{Metode Penelitian}

Penelitian ini merupakan deskriptif kuantitatif yaitu metode yang digunakan untuk mendeskripsikan keadaan secara objektif dalam bentuk angka mulai dari pengumpulan sampai penampilan hasilnya (Arikunto, 2006). Pendekatan cross sectional yaitu untuk melihat gambaran tingkat pengetahuan (Nursalam, 2013).

Variabel dalam penelitian ini menggunakan variabel tunggal yaitu pengetahuan remaja tentang kesehatan reproduksi.

Penelitian ini berlangsung di SMP Negeri 3 Selemadeg Timur. Penelitian dilakukan pada bulan 23 Mei 2019. Populasinya sebanyak 239 orang dengan sampel sebanyak 50 orang sebagai responden. Tekhnik sampel menggunakan simple random sampling dengan cara undian. Simple random sampling yaitu pengambilan sampel dengan cara acak tanpa memperhatikan strata yang ada dalam anggota populasi. Instrument yang digunakan adalah kuesioner. Data yang diperoleh diolah oleh program SPSS dengan distribusi frekuensi.

Teknik analisa data yang digunakan dalam penelitian ini dengan menggunakan analisis univariatAnilisis univariat dilakukan dengan tujuan untuk mengidentifikasi setiap variabel yang diteliti secara terpisah dengan cara membuat tabel distribusi frekuensi dari masing-masing variabel. Analisis ini hanya menggambarkan distribusi frekuensi dan prosentase dari setiap variabel.

\section{Hasil dan Pembahasan}

SMP Negeri 3 Selemadeg Timur adalah sekolah yang berada di wilayah Kecamatan Selemadeg Timur dengan alamat lengkap Jln. Pahlwan No. 1 Gadungan, Kec. Selemadeg Timur, Tabanan dengan luas tanah $50002 \mathrm{~m}^{2}$.

Hasil penelitian "Gambaran Kesehatan Reproduksi Remaja di SMP Negeri 3 Selemadeg Timur pada bulan Mei 2019 adalah sebagai berikut:

Berdasarkan tabel 1. dapat diketahui bahwa sebagian besar responden mengetahui tentang pengertian kesehatan reproduksi yaitu sebanyak 29 responden (58\%). Berdasarkan tabel 2. dapat diketahui bahwa sebagian besar responden mengetahui tentang hak kesehatan reproduksi yaitu sebanyak 26 responden $(53 \%)$.

Berdasarkan tabel 3. dapat diketahui bahwa sebagian besar responden tidak mengetahui tentang pertumbuhan dan perkmbangan remaja yaitu sebanyak 42 responden $(84,3 \%)$. Berdasarkan tabel 4 . dapat diketahui bahwa sebagian besar responden tidak mengetahui tentang fungsi reproduksi yaitu sebanyak 35 responden $(70,6 \%)$.

Berdasarkan tabel 5. dapat diketahui bahwa sebagian besar responden mengetahui tentang tanda kematangan organ reproduksi yaitu sebanyak 24 responden $(47,0 \%)$. Berdasarkan tabel 6. dapat diketahui bahwa sebagian besar responden tidak mengetahui tentang penyakit menular seksual yaitu sebanyak 42 responden $(82,3 \%)$. 
Tabel 1. Distribusi Frekuensi Pengetahuan Responden Tentang Pengertian Kesehatan Reproduksi di SMP Negeri 3 Selemadeg Timur Tahun 2019

\begin{tabular}{crcc}
\hline \multirow{2}{*}{ No. } & & Kategori & \multicolumn{2}{c}{ Hasil } \\
\cline { 3 - 4 } & & F & \% \\
\hline 1 & Tahu & 29 & 58,0 \\
\hline 2 & Tidak Tahu & 21 & 42,0 \\
\hline & Total & 50 & 100 \\
\hline
\end{tabular}

Tabel 2. Distribusi Frekuensi Pengetahuan Responden Tentang Hak Kesehatan Reproduksi di SMP Negeri 3 Selemadeg Timur Tahun 2019

\begin{tabular}{llcc}
\hline \multirow{2}{*}{ No. } & Kategori & \multicolumn{2}{c}{ Hasil } \\
\cline { 3 - 4 } & & F & \% \\
\hline 1 & Tahu & 26 & 53,0 \\
\hline 2 & Tidak Tahu & 24 & 47,0 \\
\hline & Total & 50 & 100 \\
\hline
\end{tabular}

Tabel 3. Distribusi Frekuensi Pengetahuan Responden Tentang Pertumbuhan dan Perkembangan Remaja di SMP Negeri 3 Selemadeg Timur Tahun 2019

\begin{tabular}{llcc}
\hline \multirow{2}{*}{ No. } & Kategori & \multicolumn{2}{c}{ Hasil } \\
\cline { 3 - 4 } & & $\mathbf{F}$ & $\%$ \\
\hline 1 & Tidak Tahu $(<2)$ & 42 & 84,3 \\
\hline 2 & Tahu $(2 />2)$ & 8 & 15,7 \\
\hline & Total & 50 & 100 \\
\hline
\end{tabular}

Tabel 4. Distribusi Frekuensi Pengetahuan Responden Tentang Fungsi Reproduksi di SMP Negeri 3 Selemadeg Timur Tahun 2019

\begin{tabular}{llcc}
\hline \multirow{2}{*}{ No. } & \multicolumn{1}{c}{ Kategori } & Hasil & \\
\cline { 3 - 4 } & & F & \% \\
\hline 1 & Tidak Tahu $(<3)$ & 35 & 70,6 \\
\hline 2 & Tahu $(3 />3)$ & 15 & 29,4 \\
\hline & Total & 50 & 100 \\
\hline
\end{tabular}

Tabel 5. Distribusi Frekuensi Pengetahuan Responden Tentang Tanda Kematangan Organ Reproduksi di SMP Negeri 3 Selemadeg Timur Tahun 2019

\begin{tabular}{llcc}
\hline No. & Kategori & \multicolumn{2}{c}{ Hasil } \\
\cline { 3 - 4 } & & F & \% \\
\hline 1 & Tidak Tahu $(<3)$ & 24 & 47,0 \\
\hline 2 & Tahu $(3 />3)$ & 26 & 53,0 \\
\hline & Total & 50 & 100 \\
\hline
\end{tabular}

Tabel 6. Distribusi Frekuensi Pengetahuan Responden Tentang Penyakit Menular Seksual di SMP Negeri 3 Selemadeg Timur Tahun 2019

\begin{tabular}{llcc}
\hline \multirow{2}{*}{ No. } & \multicolumn{1}{c}{ Kategori } & Hasil \\
\cline { 3 - 4 } & & F & \% \\
\hline 1 & Tidak Tahu $(<3)$ & 42 & 82,3 \\
\hline 2 & Tahu $(3 />3)$ & 8 & 17,7 \\
\hline & Total & 50 & 100 \\
\hline
\end{tabular}


Pengetahuan merupakan hasil "tahu" dan ini terjadi setelah orang melakukan penginderaan terhadap sesuatu objek tertentu. Penginderaan terjadi melalui panca indera manusia, yakni indera penglihatan, penciuman, pendengaran, perasa, dan peraba. Pengetahuan merupakan domain yang sangat penting untuk terbentuknya tindakan seseorang (Notoatmodjo, 2003).

Faktor-faktor yang mempengaruhi pengetahuan seseorang adalah tingkat pendidikan, informasi, budaya, pengalaman, sosial ekonomi, dan kepribadian. Proses belajar-mengajar yang berkualitas akan menimbulkan perubahan kearah yang lebih baik. Sumber informasi dari pengajar maupun media, sikap, kepercayaan, budaya masyarakat sangat dibutuhkan para siswi guna memperluas pengetahuan. Pengalaman pribadi serta perilaku seseorang akan dijadikan sumber pengetahuan, begitu pula dengan tingkat kemampuan seseoarang akan menambah pengetahuan (Soekanto, 2003).

Hasil penelitian menunjukan bahwa pengetahuan remaja tentang kesehatan reproduksi di SMP Negeri 3 Selemadeg Timur menunjukan masih ada sejumlah siswa yang tidak memahami tentang kesehatan reproduksi.

Menurut peneliti hal ini dipengaruhi oleh informasi yang didapatkan siswa tentang kesehatan reproduksi remaja masih belum maksimal dan responden memiliki daya serap pengetahuan yang berbeda pada masingmasing responden.

Remaja diharapkan memiliki pengetahuan yang luas khususnya tentang Kesehatan Reproduksi Remaja (KRR), sehingga remaja mampu mempersiapkan diri serta berpikir positif dalam menghadapi masa remaja yang penuh gejolak dan permasalahan. Kesehatan reproduksi adalah keadaan sehat yang menyeluruh meliputi aspek fisik, mental, dan sosial. Para remaja diharapkan mempunyai sikap tanggungjawab, sehingga mereka mampu berpikir sebab -akibat dari apapun yang akan dilakukan (Hurlock, 2004). Kurangnya tingkat pengetahuan tentang kesehatan reproduksi remaja di Indonesia menyebabkan pergeseran perilaku seksual pada remaja, namun remaja tidak mau berdiskusi tentang kesehatan reproduksi khususnya seksualitas karena dianggap sesuatu yang tabu meskipun dengan keluarga (Taufik, 2007). Remaja akan melakukan eksplorasi sendiri lewat teknologi informasi dan komunikasi, buku, majalah, film, internet, begitu bebas didapatkan, namun tidak semua informasi yang tersedia merupakan informasi yang benar, tepat, dan dapat dipertanggungjawabkan bagi kehidupan remaja, jika remaja mendapatkan informasi yang tidak benar maka hal tersebut dapat berpengaruh pada nilai kehidupan mereka (Ibrahim, 2008).

Menurut Responden dari hasil penelitian kualitatif Talib et all (2011), menyebutkan bahwa pada pelajaran Ilmu Pengetahuan Alam (IPA) guru biologi juga mengajarkan tentang bagaimana kehamilan, mencegah kehamilan, dan penyakit yang terjadi dalam hubungan seks pranikah. Selain itu guru juga menjelaskan tentang menstruasi wanita dan masa subur wanita. Menurut Mubarak (2007), Banyak faktor yang mempengaruhi pengetahuan seperti sumber informasi yang didapat, pengalaman, minat, pekerjaan, umur, dan pendidikan.

Pengetahuan pada penelitian ini terbagi menjadi 6 aspek yang diteliti oleh peneliti yaitu dari aspek pengertian kesehatan reproduksi, hak-hak reproduksi, pertumbuhan dan perkembangan organ reproduksi, fungsi reproduksi, tanda kematangan organ reproduksi dan penyakit menular seksual.

Pada aspek pengertian tentang kesehatan reproduksi, menunjukan bahwa responden mengetahui tentang pengertian kespro sebanyak 29 responden $(58 \%)$. Hal ini sesuai karena sebagian besar siswa mendapatkan sumber informasi dari guru, buku maupun media sosial.

Pada aspek hak-hak reproduksi, menunjukan bahwa responden mengetahui tentang hak kesehatan reproduksi, yang dapat diketahui dari sebagian besar responden mampu menjawab dengan baik yaitu sebanyak 26 responden (53\%).

Pada aspek pertumbuhan dan perkembangan, sebagian besar responden 
tidak mengetahui tentang pertumbuhan dan perkmbangan remaja yaitu sebanyak 42 responden $(84,3 \%)$.

Pada aspek fungsi reproduksi, sebagian besar responden tidak mengetahui tentang fungsi reproduksi yaitu sebanyak 35 responden $(70,6 \%)$.

Pada aspek tanda kematangan organ reproduksi, sebagian besar responden mengetahui tentang tanda kematangan organ reproduksi yaitu sebanyak 24 responden $(47,0 \%)$.

Pada aspek penyakit menular sksual, sebagian besar responden tidak mengetahui tentang penyakit menular seksual yaitu sebanyak 42 responden $(82,3 \%)$.

\section{Simpulan}

Berdasarkan hasil penelitian didapatkan bahwa secara umum sebagian besar siswa/i SMP Negeri 3 Selemadeg Timur yaitu:

a. Sebanyak 229 orang (58\%) mengetahui pengertian kesehatan reproduksi;

b. Sebanyak 226 orang (52\%) mengetahui hak kesehatan reproduksi;

c. Sebanyak 442 orang $(84 \%)$ tidak mengetahui pertumbuhan dan perkembangan masa remaja;

d. Sebanyak 335 orang (70\%) tidak mengetahui fungsi reproduksi;

e. Sebanyak 226 orang (52\%) mengetahui tanda kematangan organ reproduksi dan

f. Sebanyak 42 orang (84\%) tidak mengetahui penyakit menular seksual

\section{Referensi}

Arikuto, S. 2010.Prosedur Penelitian Suatu Pendekatan Praktik. Jakarta : Rhineka Cipta.

Badan Kependudukan dan Keluarga Berencana Nasional. 2008. Kurikulum dan Model Pelatihan Pengelolaan Pusat Informasi dan Konseling Kesehatan Reproduksi Remaja (PIK-KRR).Jakarta : Badan Koordinasi Keluarga Berencana Nasional

Badan Kependudukan dan Keluarga Berencana Nasional. 2012. Survei
Demografi dan Kesehatan Indonesia.Jakarta : Kementrian Kesehatan

Dewi, N.A.K. 2012. Gambaran Tingkat Pengetahuan Tentang Perkembangan Seksualitas pada Remaja Awal SMPIT Anugerah Insani Bogor. KTI. Universitas Indonesia.

Dianawati, Ajen. 2003. Pendidikan Seks untuk Remaja. Jakarta: KawanPustaka.

Hurlock, B dan Elizabeth. 2004. Psikologi Perkembangan Suatu Pendekatan Sepanjang Rentang Kehidupan(Edisi 5). Jakarta. Erlangga.

Ibrahim, 2008. Masalah Remaja. Availabel Online : [http://www.susenas.go.id]. $\operatorname{tgl} 04 / 03 / 2011$

Mubarak et all. 2007. Buku Ajar Ilmu Komunitas2, Teori dan Aplikasi dalam Praktek dengan Asuhan Keperawatan Komunitas, Keluarga, dan Gerontik.Jakarta : CV Agung Seto

Notoatmodjo, S. 2010. Ilmu Perilaku Kesehatan. Jakarta : Rineka Cipta.

Nursalam. 2013. Metodologi Penelitian Ilmu Keperawatan. Jakarta : Salemba Medika.

pkbi_jtg@telkom.net, Perkumpulan Keluarga Berencana Indonesia (PKBI) Jawa Tengah, 7 April 2009

Sugiharta, Kadek., 2004. Tumbuh Kembang remaja dan Permasalahannya. Jakarta: Sagung seto.

Talib, J., et all. 2011. Analisis on Sex Education in School Across Malaysia. Procedia-Social and Behavioral Science 59. (2012).Artikel Jurnal

Taufik, 2007. Sikap dan Perilaku Remaja. Availabel Online [http//www.Perilaku/Referen s/htm]

Utama, I.B. 2013. Gambaran Tingkat Pengetahuan Tentang Kesehatan Reproduksi pada Siswa di SMA N 1 Imogiri.KTI Program Studi Ilmu Keperawatan. UMY 